\title{
Simone de Beauvoir - Jacques-Laurent Bost, Correspondance croisée, 1937-1940
}

\section{Emanuele Kanceff}

\section{(2) OpenEdition}

12 Journals

\section{Edizione digitale}

URL: http://journals.openedition.org/studifrancesi/36707

DOI: 10.4000/studifrancesi.36707

ISSN: 2421-5856

\section{Editore}

Rosenberg \& Sellier

\section{Edizione cartacea}

Data di pubblicazione: 1 juillet 2005

Paginazione: 200

ISSN: 0039-2944

\section{Notizia bibliografica digitale}

Emanuele Kanceff, «Simone de Beauvoir - Jacques-Laurent Bost, Correspondance croisée, 1937-1940», Studi Francesi [Online], 145 (XLIX | I) | 2005, online dal 30 novembre 2015, consultato il 20 avril 2021 URL: http://journals.openedition.org/studifrancesi/36707 ; DOI: https://doi.org/10.4000/studifrancesi. 36707

Questo documento è stato generato automaticamente il 20 avril 2021.

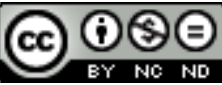

Studi Francesi è distribuita con Licenza Creative Commons Attribuzione - Non commerciale - Non opere derivate 4.0 Internazionale. 


\title{
Simone de Beauvoir - Jacques- Laurent Bost, Correspondance croisée,
} 1937-1940

\author{
Emanuele Kanceff
}

\section{NOTIZIA}

SIMONE DE BEAUVOIR - JACQUES-LAURENT BOST, Correspondance croisée, 1937-1940, édition établie, présentée et annotée par Sylvie LE BON DE BEAUVOIR, Paris, Gallimard, 2004, pp. 283.

1 Questo fittissimo corpus di lettere, spesso lunghe e significative, tra Castor (così si firma spesso Simone) e il suo beneamato Bost, è certamente un appassionato diario amoroso tra due giovani poco più che ventenni, che valeva la spesa di pubblicare al di là del fatto che si tratta di personaggi di spicco del panorama letterario del Novecento, e che sarebbe ugualmente avvincente se non ci si vedesse l'interesse biografico e di storia letteraria.

2 Non possiamo che rallegrarci di questa pubblicazione, così attenta e competente, anche se le lettere si fermano nel 1940, per motivi che la curatrice ben chiarisce nella sua brillante introduzione. 